\title{
Atopy, lung function, and obstructive airways disease after prenatal exposure to famine
}

C E Lopuhä̈, T J Roseboom, C Osmond, D J P Barker, A C J Ravelli, O P Bleker, J S van der Zee, J H P van der Meulen

\begin{abstract}
Background-Associations have been found between a large head size at birth and atopy, and between low birth weight and obstructive airways disease. A study was undertaken of people born around the time of the Dutch famine in 1944-5 to determine the effects of maternal malnutrition during specific periods of gestation on the prevalence of obstructive airways disease and atopy.
\end{abstract}

Methods-Nine hundred and twelve people aged about 50, born at term between November 1943 and February 1947 in Amsterdam, were asked about their medical history. Lung function was measured in 733 and serum concentrations of total IgE and specific IgE against mite, pollen and cat were measured in 726 . Those exposed in late, mid, and early gestation (exposed participants) were compared with those born before or conceived after the famine (non-exposed participants).

Results-Exposure to famine during gestation affected neither the concentrations of total or specific IgE nor lung function values. The prevalence of obstructive airways disease was increased in people exposed to famine in mid gestation (odds ratio adjusted for sex $1.7,95 \%$ confidence interval (CI) 1.1 to 2.6 ) and tended to be higher in those exposed in early gestation (odds ratio $1.5,95 \%$ CI 0.9 to 2.6 ).

Conclusions-The observed increase in the prevalence of obstructive airways disease in people exposed to famine in mid and early gestation was not parallelled by effects on IgE concentrations or lung function. The link between exposure to famine in mid and early gestation and obstructive airways disease in adulthood suggests that fetal lungs can be permanently affected by nutritional challenges during periods of rapid growth.

(Thorax 2000;55:555-561)

Keywords: fetal origins of disease; atopy; obstructive airways disease; famine A number of studies have shown associations atopy, and between birth weight and obstructive airways disease. Larger head circumference at birth was shown to be linked to increased serum IgE concentrations, ${ }^{1-3}$ as well as to the development of asthma in later life. ${ }^{4}$ Lower body weight at birth was shown to be associated with reduced forced expiratory volume and vital lung capacity,,$^{5-7}$ with an increased risk for asthma, ${ }^{8-13}$ as well as with increased death rates from chronic obstructive airways disease. ${ }^{6}$ Only a few studies failed to find an association between birth weight and lung function ${ }^{14}{ }^{15}$ or asthma. ${ }^{16} 17$

It is therefore likely that increased concentrations of IgE and obstructive airways disease have origins in utero. The "fetal origins" hypothesis proposes that the fetus adapts its growth rate as a response to variations in the supply of nutrients and oxygen, which may lead to permanent changes in the structure and physiology of the fetal body. ${ }^{18}$ Organs and tissues are particularly sensitive to being "programmed" by nutritional challenges during periods of rapid cell division. Different tissues and organs undergo different periods of rapid growth, and the effect of fetal undernutrition will therefore depend on its timing.

Babies who are born with a large head have grown more rapidly from early in gestation onwards. It has been speculated that, when the demands for nutrients later in gestation are no longer fully met in these rapidly growing fetuses, the differentiation of specific thymus derived helper lymphocytes from Th2 type towards Th1 type lymphocytes may be permanently impaired, ${ }^{3}$ which will in turn lead to exaggerated IgE responses and atopic phenomena later in life. ${ }^{19}$

Babies who are born with a low weight, on the other hand, might have had a compromised development of the lungs, either with respect to the major airways which are fully formed before the 16th week of gestation and grow rapidly in size between the 17th and 20th weeks, or with respect to alveolar tissue which appears at the 30th week of gestation and goes through up to $50 \%$ of its development in the short remaining time span before birth. ${ }^{20}$

The Dutch famine, a period of severe food shortage in the west of the Netherlands at the end of World War II that lasted only 5-6 months, provides a unique opportunity to test the hypothesis that undernutrition during gestation increases the occurrence of obstructive airways disease in later life by impairing the rapid development of the major airways in early and mid gestation or that of alveolar tissue or the immune system in late gestation.

\section{Methods}

SELECTION OF PARTICIPANTS

The selection procedure for the Dutch famine birth cohort and the study methods have been described in detail elsewhere. ${ }^{21}$ The cohort 
consists of 2414 singletons born alive after a gestation of at least 259 days in the Wilhelmina Gasthuis in Amsterdam between 1 November 1943 and 28 February 1947. The population registry (Bevolkingsregister) of Amsterdam traced 2254 of these 2414 babies (94.4\%). We visited 912 people at home who were still living in or close to Amsterdam, and interviewed them about their medical history and current health. Of these 912 people, 741 attended the Academic Medical Center to undergo more detailed examinations. Lung function could be successfully measured in 733 and serum IgE concentrations in 726. Mean birth weights among the 912 who were visited at home or the 741 who attended the clinic were only slightly higher than among the rest of the 2414 babies (difference adjusted for prenatal exposure famine $=12 \mathrm{~g}(\mathrm{p}=0.5)$ and $22 \mathrm{~g}(\mathrm{p}=0.3)$, respectively).

EXPOSURE TO FAMINE

Exposure to famine was defined according to the official daily rations for the general population of 21 years and older. ${ }^{22}$ The rations were about 1800 calories per day in December 1943. This figure gradually decreased to about 1400 calories in October 1944, and fell below 1000 calories on 26 November 1944. The rations rose above 1000 calories after 12 May 1945 , one week after liberation by the allied forces. In June 1945 rations were over 2000 calories. During the famine the caloric intake from protein, carbohydrate, and fat was more or less proportionately reduced. Children younger than one year were relatively protected during the Dutch famine because their official daily rations never fell below 1000 calories, and the specific nutrient components were always above the standards used by the Oxford Nutritional Survey. A dietary assessment carried out in Amsterdam immediately after the liberation of the west of the Netherlands estimated that the total daily caloric intake for an adult had been 1900 calories in October 1944, 1300 calories in February 1945, 1250 calories in April 1945, and 2450 calories at the end of May 1945, which corresponds to a caloric intake about twice that of the official rations. ${ }^{22}$

We considered a baby to be exposed to famine in utero if the average maternal daily rations during any 13 week period of gestation was below 1000 calories. Babies born between 7 January 1945 and 8 December 1945 were thus exposed. We used three periods of 16 weeks to distinguish between babies who were exposed during late gestation (born 7 January to 28 April 1945), mid gestation (29 April to 18 August 1945), and early gestation (19 August to 8 December 1945).

\section{STUDY PARAMETERS}

The medical birth records provided information about the socioeconomic status of the family, the mother, the course of the pregnancy, and the size of the baby at birth. Head circumference was estimated as $\pi$ (biparietal diameter + fronto-occipital diameter) $/ 2$. We took maternal weight to be that at the last prenatal visit within two weeks before birth.
Socioeconomic status at birth was derived from the occupation of the head of the family which was dichotomised into manual and nonmanual classes. ${ }^{23}$

The subjects visited at home were interviewed about their medical history and smoking and drinking habits. Their current socioeconomic status was coded according to the occupations of the participants or their partners, which ever was highest, on a scale ranging from 16 for the lowest to 87 for the highest status. ${ }^{24}$ The interview also contained standard questions approved by the Medical Research Council (UK) on respiratory symptoms. ${ }^{25}$ The subjects were considered to have a productive cough if they had coughed and brought up sputum on most days during three or more months in the two preceding years. We also asked whether a doctor ever told them that they had asthma, chronic bronchitis, emphysema or "chronic non-specific lung disease" (CNSLD, a general diagnosis of asthma and/or chronic obstructive pulmonary disease that was, until recently, commonly used in the Netherlands), either of which was considered as a diagnosis of obstructive airways disease.

The subjects who visited the clinic underwent spirometric tests carried out by specially trained research nurses using the Vitalograph Compact (Vitalograph Ltd, Buckingham, UK). The participants were seated and used a nose clip. After an acceptable technique had been achieved during a series of practice blows, forced expiratory volume in one second $\left(\mathrm{FEV}_{1}\right)$ and forced vital capacity (FVC) were measured at least three times. If the difference between the highest and the second highest values of $\mathrm{FEV}_{1}$ or FVC was more than $5 \%$, further measurements up to a maximum of eight were performed to improve reproducibility. ${ }^{26}$ The highest values were used in the analysis.

Blood samples were taken to measure the serum concentration of total and allergen specific IgE. Total IgE was measured with an inhibition assay for high IgE concentrations $(\geqslant 150 \mathrm{IU} / \mathrm{ml})$ and a binding assay for low concentrations $(<150 \mathrm{IU} / \mathrm{ml})$. Levels of specific IgE against house dust mite (Dermatophagoides pteronyssinus), grass pollen (Lolium perenne), and cat dander (Felis domesticus) were measured with a radioallergosorbant test (RAST).${ }^{27}$ Each sample was tested in duplicate and the mean of these two results was used in the analyses. The results were expressed in international units using an in-house standard, calibrated against the World Health Organisation standard. ${ }^{28}$ We considered specific IgE to be present if the RAST indicated a serum concentration of $\geqslant 0.5 \mathrm{IU} / \mathrm{ml}$.

STATISTICAL ANALYSIS

The allergic and respiratory outcome measures of subjects prenatally exposed to famine (in late, mid and early gestation) were compared with those of non-exposed people (those born before or conceived after the famine pooled together), always adjusting for sex. We used linear regression to adjust the lung function measurements for the participant's sex, height and age. Linear regression was also used to 
Table 1 Maternal characteristics, birth outcomes, and adult characteristics according to prenatal exposure to famine

\begin{tabular}{|c|c|c|c|c|c|c|c|}
\hline & \multirow[b]{2}{*}{$\begin{array}{l}\text { Born } \\
\text { before } \\
\text { famine } \\
n=264\end{array}$} & \multicolumn{3}{|c|}{ Exposed to famine } & \multirow[b]{2}{*}{$\begin{array}{l}\text { Conceived } \\
\text { after famine } \\
n=284\end{array}$} & \multirow[b]{2}{*}{$\begin{array}{l}\text { Mean }(S D) \\
n=912\end{array}$} & \multirow[b]{2}{*}{$\begin{array}{l}\text { Missing } \\
\text { observations }\end{array}$} \\
\hline & & $\begin{array}{l}\text { In late } \\
\text { gestation } \\
n=140\end{array}$ & $\begin{array}{l}\text { In mid } \\
\text { gestation } \\
n=137\end{array}$ & $\begin{array}{l}\text { In early } \\
\text { gestation } \\
n=87\end{array}$ & & & \\
\hline Men & $49 \%$ & $46 \%$ & $39 \%$ & $41 \%$ & $50 \%$ & $46 \%$ & 0 \\
\hline \multicolumn{8}{|l|}{ Maternal characteristics } \\
\hline Age (years) & 28.9 & 30.8 & 28.8 & 27.9 & 28.6 & $29.0(6.4)$ & 0 \\
\hline Primipara (\%) & 37.1 & 25.7 & 34.3 & 36.8 & 35.2 & 34.3 & 0 \\
\hline Weight end pregnancy (kg) & 66.4 & 62.8 & 64.1 & 68.4 & 68.5 & $66.3(8.7)$ & 117 \\
\hline Manual class (\%) & 78.5 & 70.3 & 68.4 & 66.2 & 70.0 & 71.8 & 164 \\
\hline \multicolumn{8}{|l|}{ Birth outcomes } \\
\hline Weight (g) & 3372 & 3137 & 3236 & 3481 & 3425 & 3325 (474) & 0 \\
\hline Body length (cm) & 50.6 & 49.4 & 49.8 & 51.0 & 50.4 & $50.3(2.2)$ & 8 \\
\hline Head circumference $(\mathrm{cm})$ & 32.9 & 32.3 & 32.1 & 33.0 & 33.1 & $32.8(1.5)$ & 8 \\
\hline Ponderal index $\left(\mathrm{kg} / \mathrm{m}^{3}\right)$ & 26.0 & 25.9 & 26.2 & 26.1 & 26.6 & $26.2(2.4)$ & 8 \\
\hline \multicolumn{8}{|l|}{ Characteristics at age 50} \\
\hline Weight $(\mathrm{kg})$ & 78.8 & 78.2 & 76.5 & 80.2 & 80.4 & $79.0(15.3)$ & 5 \\
\hline Height $(\mathrm{cm})$ & 170.6 & 170.1 & 168.4 & 170.4 & 170.3 & $170.1(9.1)$ & 6 \\
\hline Current smoker (\%) & 39.0 & 37.9 & 32.8 & 47.1 & 34.9 & 37.4 & 0 \\
\hline Socioeconomic status & 46.2 & 49.7 & 48.1 & 47.6 & 47.3 & $47.5(13.8)$ & 0 \\
\hline
\end{tabular}

Values are mean except where given as \%.

analyse the effects of prenatal famine exposure on continuously distributed variables. Before analysis the serum concentration of total $\mathrm{IgE}$ was log transformed because of its skewed distribution. Its results are therefore given as geometric means and standard deviations, and differences between exposed and non-exposed subjects are relative differences and expressed as percentages of the means of non-exposed subjects. Logistic regression for dichotomous outcome variables was used to calculate odds ratios which can be considered as relative risks. Differences were considered to be statistically significant if two sided $\mathrm{p}$ values were less than 0.05; $95 \%$ confidence intervals were also computed.

For a relatively large number of participants we did not have data of socioeconomic status at birth (dichotomised into manual and nonmanual class). When adjusting for this we added an extra category in the regression model for those participants with missing values.

\section{Results}

CHARACTERISTICS OF STUDY POPULATION

The characteristics of the participants according to prenatal exposure to famine are shown in table 1 . Fewer men were included in the groups exposed to famine in mid and early gestation. Mothers exposed in late pregnancy were older and less often primiparous, whereas mothers of subjects exposed in early gestation were slightly younger than those who were not exposed to famine prenatally. The body weight of mothers measured within two weeks of the delivery was lower among those exposed to famine in late and mid pregnancy. Subjects exposed to famine in late and mid gestation had a lower birth weight, body length, and ponderal index (weight divided by the cube of length) and smaller heads. Those exposed to famine in early gestation had a higher weight and body length at birth, and a higher body weight at age 50, than non-exposed people. The frequency of being a current smoker was higher among people exposed in early gestation than among people in the other exposure groups.

\section{PRENATAL EXPOSURE TO FAMINE}

No effects of prenatal exposure to famine were found on the serum concentration of total IgE (tables 2 and 3). Subjects exposed to famine in late gestation, however, had specific $\operatorname{IgE}$ directed to grass pollen more often than non-exposed participants, whilst the proportion of people having specific IgE against

Table 2 Serum IgE concentrations, lung function measures, and prevalence of respiratory symptoms and disease according to prenatal exposure to famine

\begin{tabular}{|c|c|c|c|c|c|c|c|}
\hline & \multirow{2}{*}{$\begin{array}{l}\text { Born } \\
\text { before } \\
\text { famine }\end{array}$} & \multicolumn{3}{|c|}{ Exposed to famine } & \multirow[b]{2}{*}{$\begin{array}{l}\text { Conceived } \\
\text { after famine }\end{array}$} & \multirow[b]{2}{*}{ Mean (SD) } & \multirow[b]{2}{*}{$\begin{array}{l}\text { Missing } \\
\text { observations }\end{array}$} \\
\hline & & $\begin{array}{l}\text { In late } \\
\text { gestation }\end{array}$ & $\begin{array}{l}\text { In mid } \\
\text { gestation }\end{array}$ & $\begin{array}{l}\text { In early } \\
\text { gestation }\end{array}$ & & & \\
\hline IgE & $n=207$ & $n=119$ & $n=106$ & $n=64$ & $n=230$ & $n=726$ & \\
\hline Total IgE $(\mathrm{IU} / \mathrm{ml})^{\star}$ & 31.0 & 27.2 & 28.9 & 27.9 & 33.1 & $30.4(4.6)$ & 0 \\
\hline \multicolumn{8}{|l|}{ Prevalence of specific IgE } \\
\hline Cat & $7.2 \%$ & $6.7 \%$ & $6.6 \%$ & $6.3 \%$ & $4.3 \%$ & $6.1 \%$ & 0 \\
\hline House dust mite & $13.5 \%$ & $17.6 \%$ & $17.0 \%$ & $17.2 \%$ & $17.0 \%$ & $16.1 \%$ & 0 \\
\hline Pollen & $7.7 \%$ & $16.0 \%$ & $6.6 \%$ & $3.1 \%$ & $11.3 \%$ & $9.6 \%$ & 0 \\
\hline Any of these three & $18.8 \%$ & $26.9 \%$ & $24.5 \%$ & $18.8 \%$ & $24.8 \%$ & $22.9 \%$ & 0 \\
\hline Lung function & $n=210$ & $n=118$ & $n=107$ & $n=67$ & $n=231$ & $n=733$ & \\
\hline $\mathrm{FEV}_{1}(1)^{\star \star}$ & 3.1 & 3.1 & 3.0 & 3.0 & 3.1 & $3.1(0.6)$ & 0 \\
\hline $\operatorname{FVC}(1)^{\star \star}$ & 4.3 & 4.4 & 4.2 & 4.2 & 4.2 & $4.3(0.7)$ & 0 \\
\hline $\mathrm{FEV}_{1} / \mathrm{FVC}^{\star \star}$ & 0.72 & 0.72 & 0.72 & 0.72 & 0.74 & $0.72(0.1)$ & 0 \\
\hline Respiratory symptoms and disease & $n=264$ & $n=140$ & $n=137$ & $\mathrm{n}=87$ & $n=284$ & $n=912$ & \\
\hline Wheeze & $8.7 \%$ & $9.3 \%$ & $19.0 \%$ & $12.6 \%$ & $12.0 \%$ & $11.7 \%$ & 0 \\
\hline Productive cough & $4.2 \%$ & $5.8 \%$ & $8.0 \%$ & $2.3 \%$ & $3.2 \%$ & $4.5 \%$ & 4 \\
\hline Obstructive airways disease & $15.5 \%$ & $15.0 \%$ & $24.8 \%$ & $23.0 \%$ & $17.3 \%$ & $18.1 \%$ & 0 \\
\hline
\end{tabular}

Values are mean except where given as \%.

${ }^{\star}$ Geometric means and standard deviation.

${ }^{\star \star}$ Means adjusted for sex, height and age. 
Table 3 Effects of prenatal famine exposure expressed as differences (95\% confidence intervals) according to prenatal exposure to famine compared with non-exposed people (born before or conceived after the famine)

\begin{tabular}{|c|c|c|c|}
\hline & \multicolumn{3}{|l|}{ Exposed to famine } \\
\hline & In late gestation & In mid gestation & In early gestation \\
\hline \multicolumn{4}{|l|}{$\operatorname{IgE}$} \\
\hline \multicolumn{4}{|l|}{ Relative differences ${ }^{\star}$} \\
\hline Serum concentration total IgE & $-14.2 \%(-36.9$ to 16.6$)$ & $-7.3 \%(-32.8$ to 28.0$)$ & $-11.5 \%(-40.5$ to 31.8$)$ \\
\hline \multicolumn{4}{|l|}{ 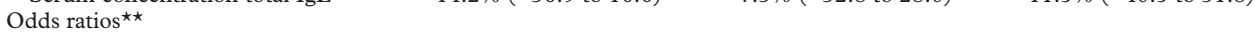 } \\
\hline \multicolumn{4}{|l|}{ Prevalence of specific IgE } \\
\hline Cat & $1.2(0.5$ to 2.6$)$ & $1.1(0.5$ to 2.6$)$ & $1.0(0.4$ to 3.1$)$ \\
\hline House dust mite & $1.2(0.7$ to 2.1$)$ & $1.2(0.7$ to 2.1$)$ & $1.2(0.6$ to 2.4$)$ \\
\hline Pollen & $1.8(1.0$ to 3.3$)$ & $0.7(0.3$ to 1.6$)$ & $0.3(0.1$ to 1.3$)$ \\
\hline Any of these three & $1.3(0.8$ to 2.1$)$ & $1.2(0.7$ to 2.0$)$ & $0.8(0.4$ to 1.6$)$ \\
\hline \multicolumn{4}{|l|}{ Lung function } \\
\hline \multicolumn{4}{|l|}{ Absolute differences $(95 \% \mathrm{CI})^{\star \star \star}$} \\
\hline $\mathrm{FEV}_{1}(\mathrm{l})$ & $0.03(-0.08$ to 0.14$)$ & $-0.06(-0.17$ to 0.06$)$ & $-0.06(-0.20$ to 0.08$)$ \\
\hline FVC (1) & $0.06(-0.07$ to 0.19$)$ & $-0.06(-0.19$ to 0.07$)$ & $-0.07(-0.23$ to 0.09$)$ \\
\hline $\mathrm{FEV}_{1} / \mathrm{FVC}(\times 100)$ & $-0.4(-2.1$ to 1.4$)$ & $-0.3(-2.1$ to 1.6$)$ & $-0.6(-2.9$ to 1.6$)$ \\
\hline \multicolumn{4}{|l|}{ Respiratory symptoms and disease } \\
\hline \multicolumn{4}{|l|}{ Odds ratios $(95 \% \mathrm{CI})^{\star \star}$} \\
\hline Wheeze & $0.9(0.5$ to 1.6$)$ & $1.9(1.2$ to 3.2$)$ & $1.2(0.6$ to 2.4$)$ \\
\hline Productive cough & $1.6(0.7$ to 3.7$)$ & $2.2(1.1$ to 4.8$)$ & $0.6(0.1$ to 2.7$)$ \\
\hline Obstructive airways disease & $0.9(0.5$ to 1.5$)$ & $1.7(1.1$ to 2.6$)$ & $1.5(0.9$ to 2.6$)$ \\
\hline
\end{tabular}

$\star$ Percentages of the means in non-exposed people, adjusted for sex.

$\star \star$ Ratio of odds in exposed to odds in non-exposed people, adjusted for sex.

$\star \star \star$ Differences between means of exposed and non-exposed people, adjusted for sex, height and age

house dust mite or cat dander did not differ according to prenatal exposure to famine.

Mean lung function $\left(\mathrm{FEV}_{1}, \mathrm{FVC}\right.$, and $\mathrm{FEV}_{1} /$ FVC ratio) did not differ between the two groups (tables 2 and 3 ). Those exposed in mid gestation had wheezing more often than non-exposed subjects and they were also told more frequently by a doctor that they had obstructive airways disease (tables 2 and 3). The proportion with obstructive airways disease seemed also to be increased in subjects exposed to famine in early gestation.

The results were hardly influenced by adjustment for age and parity of the mother and socioeconomic status at birth, as well as for current smoking and socioeconomic status at the age of 50. After allowing for these variables we obtained an odds ratio for obstructive airways disease of 1.7 (95\% CI 1.1 to 2.8 ) in subjects exposed in mid gestation and of 1.4 ( $95 \%$ CI 0.8 to 2.6 ) in those exposed in early gestation.

SIZE AT BIRTH

Birth weight was not associated with serum concentrations of total or specific IgE, lung function results, or prevalence of respiratory symptoms or obstructive disease (table 4), neither was head circumference linearly associated with any of the allergic or respiratory measures (table 5), although subjects with head circumferences of more than $34 \mathrm{~cm}$ had higher total $\operatorname{IgE}$ concentrations than the other participants (28.1 versus $42.3 \mathrm{IU} / \mathrm{ml}$, relative difference adjusted for sex and prenatal exposure to famine $40 \%(95 \%$ CI 5 to 87$), p=0.02)$. This difference did not change when we adjusted for age and parity of the mother and socioeconomic status at birth, as well as for current smoking and socioeconomic status at the age of 50 .

Birth length and ponderal index were not associated with allergic or respiratory parameters ( $p$ for trend always $\geqslant 0.2$ ) except that $\mathrm{FEV}_{1}$ and FVC, adjusted for sex, height and age, increased with ponderal index $\left(\mathrm{FEV}_{1}\right.$ from 3.011 if the ponderal index was $\leqslant 25 \mathrm{~kg} / \mathrm{m}^{3}$ to 3.141 if the ponderal index was $>27 \mathrm{~kg} / \mathrm{m}^{3}$ (p for trend =0.1) and FVC from 4.171 to 4.331 $(\mathrm{p}$ for trend $=0.04)$ ). The $\mathrm{FEV}_{1} / \mathrm{FVC}$ ratio was not associated with ponderal index ( 0.725 with ponderal index of $\leqslant 25 \mathrm{~kg} / \mathrm{m}^{3}$ and 0.726 with ponderal index of $>27 \mathrm{~kg} / \mathrm{m}^{3}$; p for trend $=$ $0.7)$.

Table 4 Serum IgE concentration, lung function measures, and prevalence of respiratory symptoms and disease according to birth weight

\begin{tabular}{|c|c|c|c|c|c|c|}
\hline & \multicolumn{4}{|c|}{ Birth weight $(g)$} & \multirow[b]{2}{*}{ Total } & \multirow[b]{2}{*}{$p$ for trend ${ }^{\star}$} \\
\hline & $\leqslant 2750$ & -3250 & -3750 & $>3750$ & & \\
\hline $\operatorname{IgE}$ & $n=66$ & $n=240$ & $n=271$ & $n=149$ & $n=726$ & \\
\hline Total IgE $(\mathrm{IU} / \mathrm{ml})^{\star \star}$ & 27.2 & 31.0 & 29.0 & 33.9 & $30.4(4.6)$ & 1.0 \\
\hline Prevalence of specific IgE (cat, mite or pollen) & $22.7 \%$ & $21.3 \%$ & $24.0 \%$ & $23.5 \%$ & $22.9 \%$ & 0.7 \\
\hline Lung function & $n=65$ & $n=242$ & $n=275$ & $n=151$ & $n=733$ & \\
\hline $\mathrm{FEV}_{1}(1)^{\star \star \star}$ & 3.11 & 3.08 & 3.09 & 3.14 & $3.10(0.62)$ & $0.6^{\star \star \star \star}$ \\
\hline $\operatorname{FVC}(1)^{\star \star \star}$ & 4.30 & 4.26 & 4.27 & 4.35 & $4.29(0.73)$ & $0.6^{\star \star \star \star}$ \\
\hline $\mathrm{FEV}_{1} / \mathrm{FVC}^{\star \star \star}$ & 0.722 & 0.728 & 0.724 & 0.727 & $0.725(0.108)$ & $0.8^{\star \star \star \star}$ \\
\hline Respiratory symptoms and disease & $n=87$ & $n=302$ & $n=334$ & $n=189$ & $n=912$ & \\
\hline Wheeze & $13.8 \%$ & $12.3 \%$ & $12.0 \%$ & $9.5 \% \%$ & $11.7 \%$ & 0.8 \\
\hline Productive cough & $4.6 \%$ & $5.6 \%$ & $4.8 \%$ & $2.1 \%$ & $4.5 \%$ & 0.7 \\
\hline Obstructive airways disease & $17.2 \%$ & $17.9 \%$ & $20.7 \%$ & $14.3 \%$ & $18.1 \%$ & 1.0 \\
\hline
\end{tabular}

Values are mean except where given as \%.

${ }^{\star} \mathrm{p}$ value adjusted for sex.

$\star \star$ Geometric means and standard deviation.

$\star \star \star$ Means adjusted for sex, height and age.

$\star \star \star \star$ p value also adjusted for height and age. 
Table 5 Serum IgE concentration, lung function measures, and prevalence of respiratory symptoms and disease according to head circumference at birth

\begin{tabular}{|c|c|c|c|c|c|c|}
\hline & \multicolumn{4}{|c|}{ Head circumference $(\mathrm{cm})$} & \multirow[b]{2}{*}{ Total } & \multirow[b]{2}{*}{$p$ for trend ${ }^{\star}$} \\
\hline & $\leqslant 32$ & -33 & -34 & $>34$ & & \\
\hline IgE & $n=192$ & $n=240$ & $n=147$ & $n=139$ & $n=718$ & \\
\hline Total IgE $(\mathrm{IU} / \mathrm{ml})^{\star \star}$ & 29.5 & 24.4 & 31.3 & 42.3 & $30.5(4.6)$ & 0.1 \\
\hline Prevalence of specific IgE (cat, mite or pollen) & $21.4 \%$ & $20.4 \%$ & $26.5 \%$ & $25.2 \%$ & $22.8 \%$ & 0.5 \\
\hline Lung function & $n=194$ & $n=239$ & $n=150$ & $n=142$ & $n=725$ & \\
\hline $\mathrm{FEV}_{1}(1)^{\star \star \star}$ & 3.09 & 3.13 & 3.09 & 3.06 & $3.09(0.54)$ & $0.5^{\star \star \star \star}$ \\
\hline$\star \mathrm{FVC}(1)^{\star \star \star}$ & 4.32 & 4.32 & 4.22 & 4.22 & $4.27(0.65)$ & $0.2^{\star \star \star \star}$ \\
\hline $\mathrm{FEV}_{1} / \mathrm{FVC}^{\star \star \star}$ & 0.717 & 0.726 & 0.735 & 0.730 & $0.727(0.081)$ & $0.2^{\star \star \star \star}$ \\
\hline Respiratory symptoms and disease & $n=251$ & $n=301$ & $n=178$ & $n=174$ & $n=904$ & \\
\hline Wheeze & $13.9 \%$ & $11.0 \%$ & $11.8 \%$ & $9.8 \%$ & $11.7 \%$ & 0.6 \\
\hline Productive cough & $6.0 \%$ & $4.7 \%$ & $3.4 \%$ & $3.5 \%$ & $4.6 \%$ & 0.9 \\
\hline Obstructive airways disease & $8.7 \%$ & $17.9 \%$ & $21.9 \%$ & $13.2 \%$ & $18.0 \%$ & 0.7 \\
\hline
\end{tabular}

Values are mean except where given as $\%$.

${ }^{\star} \mathrm{p}$ value adjusted for sex.

$\star \star$ Geometric means and standard deviation.

$\star \star \star$ Means adjusted for sex, height and age.

$\star \star \star \star \mathrm{p}$ value also adjusted for height and age.

\section{Discussion}

The prevalence of respiratory symptoms and obstructive airways disease was increased in subjects who had been exposed to famine in mid gestation, and the prevalence of disease tended to be higher also in those exposed to famine in early gestation. These observations were not parallelled by the effects of prenatal exposure to famine on serum concentrations of IgE and on lung function volumes. This suggests that the observed increase in the prevalence of symptoms and disease is attributable to increased bronchial reactivity rather than to irreversible airflow obstruction or atopic disease, although we have not measured bronchial reactivity directly.

METHODOLOGICAL CONSIDERATIONS

The higher prevalence of respiratory complaints and obstructive airways disease among people exposed to famine in mid gestation could not be explained by an effect of season of birth. The prevalence of wheezing, productive cough, and obstructive airways disease in those not exposed to famine prenatally but born at the same time of the year as those exposed to famine in mid gestation (between 29 April and 18 August) was not increased $(3.4 \%, 9.8 \%$, and $15.6 \%$, respectively) compared with nonexposed people born outside that period $(4.5 \%, 12.6 \%$, and $19.8 \%)$. On the other hand, the higher prevalence of specific IgE against grass pollen in subjects exposed to famine in late gestation (born between 7 January and 28 April) seemed to be due to a seasonal effect. Subjects who were not exposed to famine during gestation but were born at the same time of the year as those exposed to famine in late gestation had specific IgE against pollen more frequently than other non-exposed subjects ( $13.2 \%$ versus $7.7 \%$ ).

In this respect, it also important to note that the prevalence of specific IgE against cats decreased with date of birth from $7.2 \%$ in subjects born before to $4.3 \%$ in those conceived after the famine (table 2). The simplest explanation for this time trend is that the number of cats rapidly declined during the famine when it became very difficult for their owners to feed them, and some people even ate them as an addition to the falling rations. Both the effect of season of birth on sensitisation to grass pollen and the decline of sensitisation to cats with date of birth seem therefore to support other evidence that there is a "sensitive period" in the first months of life during which allergen exposure is more likely to prime for allergy later in life. $^{29}$

Our results with respect to respiratory complaints and obstructive airways disease are based on the responses of subjects to questions asked during the home interview and were not verified against medical records. We did not find effects of famine exposure on other complaints of chronic diseases (psychiatric or orthopaedic), which indicates that the effects of famine exposure in mid and early gestation were specific for respiratory complaints and obstructive airways disease, and could not be explained by a general tendency to complain more about health.

SIZE AT BIRTH

Subjects born with large heads had higher plasma concentrations of total IgE, which is consistent with previous studies performed in childhood and adult life. ${ }^{1-3} \mathrm{~A}$ large head size at birth has been interpreted as a sign of rapid fetal growth from early on in gestation that makes the fetus vulnerable to undernutrition in late gestation. ${ }^{30}$ We did not replicate frequently reported associations between low birth weight and reduced lung function measures or respiratory symptoms and disease, but we did find that those born as thin babies tended to have lower $\mathrm{FEV}_{1}$ and FVC values, but not lower $\mathrm{FEV}_{1} / \mathrm{FVC}$ ratios, which indicates a restrictive rather than an obstructive deficit. Thinness at birth is also thought to result from fetal undernutrition in late gestation. ${ }^{31}$ The restrictive deficit observed in thin babies is in keeping with an impairment of lung growth in late gestation, as alveoli appear only in the last trimester of gestation. ${ }^{20}$

\section{PRENATAL EXPOSURE TO FAMINE AND FETAL} GROWTH

The interpretation of the associations between a large head circumference at birth and a high total IgE concentration, and between thinness and a restrictive respiratory deficit as effects of fetal undernutrition in late gestation, seems to 
be in conflict with the failure to find effects of maternal malnutrition in late gestation on any of these outcomes. However, babies born during the famine period-and therefore exposed to famine in late gestation-were on average only about $250 \mathrm{~g}$ lighter than babies who were not exposed to famine in utero, and this famine related reduction in birth weight is relatively small compared with the routinely observed variations in birth weights. In other words, the Dutch famine has to be considered as a severe but short nutritional challenge superimposed on other determinants of the maternoplacental supply of nutrients to the fetus. ${ }^{32}$

UNDERLYING MECHANISMS

Studies in rats have shown more pronounced pulmonary injuries after sulphur dioxide induced bronchial injuries in young animals that had been exposed in utero to a low protein maternal diet than in non-exposed animals, which may reflect programming of the immune system and antioxidant defences. ${ }^{33}$ Furthermore, rats exposed to a low protein diet during gestation had a blunted acute phase response to endotoxin that was particularly distinct in lung tissue. ${ }^{34}$ Another study in rats reported decreased binding of dexamethasone to lung receptors in fetuses exposed to a low protein diet. $^{35}$ The results of these experimental studies indicate that nutritional challenges during gestation might induce an increased susceptibility to pulmonary injury later in life which is compatible with our observation of an increased risk of obstructive airways disease in subjects exposed to famine in mid and early gestation.

An exaggerated IgE response and atopic disease are associated with the presence of $\mathrm{T}$ helper type 2 lymphocytes (Th2) in adult life. ${ }^{19}$ Normal fetal and newborn immune responses to environmental antigens are Th2 skewed. ${ }^{36}$ During the first years of life a gradual shift towards Th1 dominated immune responses takes place. Predisposition towards atopy and related disorders might result from an impairment in the shutdown of the Th2 type immune response during late gestation and in the first years after birth. One explanation for the association between a large head circumference and an increased IgE level is that fetal undernutrition in late gestation affects the production of cytokines which, in turn, influences the direction of the differentiation of the lymphocytes at that time. Another explanation is that high total IgE levels reflect an impaired growth of the thymus during its rapid growth in late gestation. ${ }^{3}$ However, the association between head circumference and total $\mathrm{IgE}$ is not accompanied by an increase in persistent allergen specific IgE responses to environmental allergens in the first months of life.

\section{CONCLUSIONS}

The link between head circumference and total $\mathrm{IgE}$ in adulthood confirms earlier studies, but no associations were found between maternal malnutrition and the development of allergic conditions. The link between maternal malnutrition in mid and early gestation and obstructive airways disease in adulthood supports the hypothesis that fetal undernutrition permanently affects the structure and physiology of the airways during "critical periods" of development that coincide with periods of rapid growth.

We gratefully acknowledge the willing cooperation of the participants. We thank Marjan Loep, Mieneke Vaas, Lydia Stolwijk, Yvonne Graafsma, Jokelies Knopper, and Maartje de Ley and the nurses of the Special Research Unit, Academic Medical Center, Amsterdam, for collecting the data, and we thank Dr Carel Roos and Niesje Verhey, Department of Pulmonology, Academic Medical Center, Amsterdam for their essential help with the spirometric tests. Professor Rob Aalberse, Central waboratory of the Blood Transfusion Service and Laboratory for Experimental and Clinical Immunology, University of Amsterdam, is gratefully acknowledged for allowing us to perform the IgE antibody assays in his laboratory. We also thank
the Gemeentearchief of Amsterdam for seeking the birth records and the Bevolkingsregister of Amsterdam for tracing the records and
subjects.

Funding: The study was funded by the Medical Research Council, UK, Stichting Astma Bestrijding, Wellbeing, UK, and the Academic Medical Center, Amsterdam.

1 Oryszczyn MP, Annesi-Maesano I, Campagna D, et al. Head circumference at birth and maternal factors related to cord blood total IgE. Clin Exp Allergy 1999;29:334-41.

2 Gregory A, Doull I, Pearce N, et al. The relationship between anthropometric measurements at birth: asthma and atopy in childhood. Clin Exp Allergy 1999;29:330-3.

3 Godfrey KM, Barker DJP, Osmond C. Disproportionate fetal growth and raised IgE concentration in adult life. Clin Exp Allergy 1994;24:641-8.

4 Fergusson DM, Crane J, Beasley R, et al. Perinatal factors and atopic disease in childhood. Clin Exp Allergy 1997;27: 1394-401.

5 Rona RJ, Gulliford MC, Chinn S. Effects of prematurity and intrauterine growth and respiratory health and lung and intrauterine growth and respiratory healt

6 Barker DJP, Godfrey KM, Fall C, et al. Relation of birth weight and childhood respiratory infection to adult lung function and death from chronic obstructive airways disease. BMF 1991;303:671-5.

7 Stein CE, Kumaran K, Fall CHD, et al. Relation of fetal growth to adult lung function in south India. Thorax 1997; 52:895-9.

8 Arshad SH, Stevens M, Hide DW. The effect of genetic and environmental factors on the prevalence of allergic $504-11$

9 Schaubel D, Johansen H, Dutta $M$, et al. Neonatal characteristics as risk factors for preschool asthma. $f$ Asthma 1996;33:255-64.

10 Oliveti JF, Kercsmar CM, Redline S. Pre- and perinatal risk factors for asthma in inner city African-American children. Am f Epidemiol 1996;143:570-7.

11 Slezak JA, Persky VW, Kviz FJ, et al. Asthma prevalence and Slezak JA, Persky VW, Kviz FJ, et al. Asthma prevalence and
risk factors in selected Head Start Sites in Chicago. 7 risk factors in selected

12 Seidman DS, Laor A, Gale R, et al. Is low birth weight a risk factor for asthma during adolescence?. Arch Dis Child 1991;66:584-7

13 Shaheen SO, Sterne JA, Montgomery SM, et al. Birth weight, body mass index and asthma in young adults. Thorax 1999;54:396-402

14 Matthes JWA, Lewis PA, Davies DP, et al. Birth weight at term and lung function in adolescence: no evidence for a programmed effect. Arch Dis Child 1995;73:231-4.

15 Shaheen SO, Sterne JAC, Tucker JS, et al. Birth weight, childhood lower respiratory tract infection, and adult lung function. Thorax 1998,53:549-53.

16 Sears MR, Holdaway MD, Flannery EM, et al. Parental and neonatal risk factors for atopy, airway hyper5:392-8. Kelly YJ, Brabin BJ, Milligan P, et al. Maternal asthma, premature birth, and the risk of respiratory morbidity in

18 Barker DJP. Mothers, babies and health in later life. 2nd ed. Edinburgh: Churchill Livingstone, 1998 .

19 Romagnani S. Human TH1 and TH2 subsets: regulation of Romagnani S. Human TH1 and TH2 subsets: regulation of
differentiation and role in protection and immunopathology. Int Arch Allergy Immunol 1992;98:279-85.

20 Shaheen SO, Barker DJP. Early lung growth and chronic airflow obstruction. Thorax 1994;49:533-6.

21 Ravelli ACJ, van der Meulen JHP, Michels RPJ, et al. Glucose tolerance in adults after prenatal exposure to the Dutch famine. Lancet 1998;351:173-7.

22 Burger GCE, Drummond JC, Sandstead HR. Malnutrition and starvation in western Netherlands. 's Gravenhage: Staatsuitgeverij, 1948

23 Stein ZA, Susser MW, Saenger G, et al. Famine and human development: the Dutch hunger winter of 1944-45. New York: Oxford University Press, 1975.

24 Bakker B, Sieben I. Maten voor prestige, sociaalexonomische status en sociale klasse voor de standaard beroepenclassificatie 1992. (Measures of prestige, socioeconomic status and social class for the standard occupation classification.) Sociale Wetenschappen 1997;40: $1-22$ (in Dutch). 
25 Medical Research Council. Questionnaire on respiratory symptoms. London: MRC, 1986.

26 American Thoracic Society Statement. Standardisation of spirometry: 1987 update. Am Rev Respir Dis 1987;136 1285-98.

27 Witteman AM, Stapel SO, Perdok GJ, et al. The relationship between RAST and skin test results in patients with asthma or rhinitis: a quantitative study with purified major allergens. F Allergy Clin Immunol 1996;97:16-25.

28 Schuurman J, Pardok GJ, Lourens TE, et al. Production of a mouse/human chimeric IgE monoclonal antibody to the house dust mite allergen $\operatorname{Der} p 2$ and its use for the absolute quantification of allergen-specific IgE. F Allergy Clin Immunol 1997;99:545-50.

29 Aalberse RC, Nieuwenhuys EJ, Hey M, et al. 'Horoscope effect' not only for seasonal but also for non-seasonal allergens. Clin Exp Allergy 1992;22:1003-6.

30 Harding J, Liu L, Evans P, et al. Intrauterine feeding of the growth retarded fetus: can we help? Early Hum Dev 1992; 29:193-7.
31 McCance RA, Widdowson EM. The determinants of growth and form. Proc $R$ Soc Lond B Biol Sci 1974:185:1grow.

32 Bloomfield FH, Harding JE. Experimental aspect of nutrition and fetal growth. Fetal Matern Med Rev 1998;10: 91-107.

33 Langley-Evans SC, Phillips GJ. Jackson AA. Fetal exposure to low protein maternal diet alters the susceptibility of young adult rats to sulfur dioxide-induced lung injury. $\mathcal{f}$ young adult rats to sul:

34 Langley SC, Seakins M, Grimble RF, et al. The acute phase response of adult rats is altered by in utero exposure to maternal low protein diets. F Nutr 1994;124:1588-96.

35 Mulay S, Browne CA, Varma DR, et al. Placental hormones, nutrition, and fetal development. Federation Proc 1980;39: 261-5.

36 Holt PG, Sly PD. Allergic respiratory disease: strategic targets for primary prevention in childhood. Thorax 1997;52: $1-4$. 